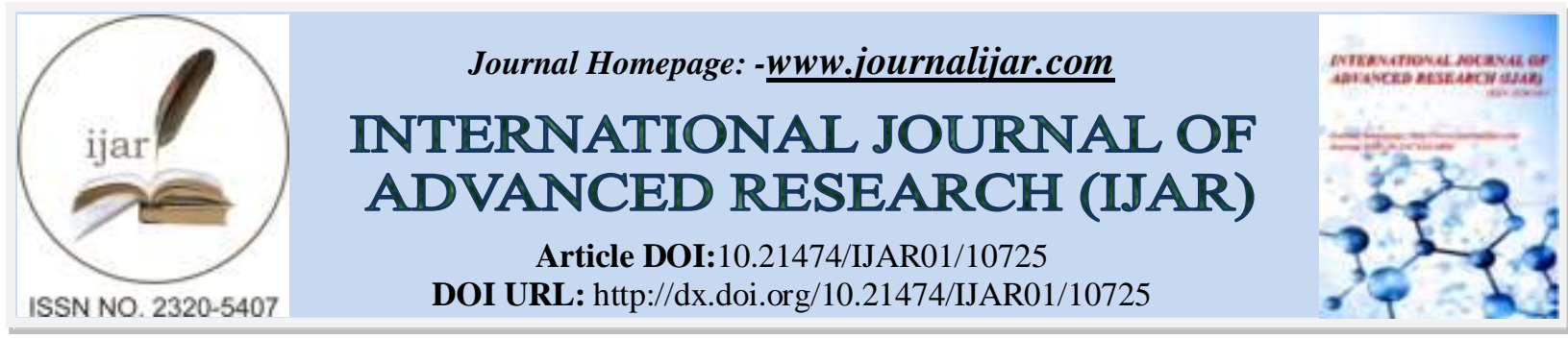

RESEARCH ARTICLE

\title{
DETERMINANTS OF FARMERS' PARTICIPATION AND INTENSITY OF PARTICIPATION IN GROUNDNUT COMMERCIALIZATION: EVIDENCE FROM BABILE DISTRICT, OROMIA NATIONAL REGIONAL STATE, ETHIOPIA
}

\section{Oromia Megersa Gelana ${ }^{1}$, Chanyalew Seyoum Aweke $(\mathrm{PhD})^{2}$ and Eric Ndemo Okoyo $(\mathrm{PhD})^{2}$}

1. Fedis Agricultural Research Centre, Oromia Agricultural Research Institute, Ethiopia.

2. Department of Rural Development and Agricultural Extension, Haramaya University, Ethiopia.

\section{Manuscript Info}

Manuscript History

Received: 25 January 2020

Final Accepted: 27 February 2020

Published: March 2020

Key words:-

Farmers, Groundnut,

Commercialization, Double Hurdle,

Babile District

\begin{abstract}
This study was conducted in Babile district to examine the determinants of farmers' participation decision and intensity of participation ingroundnut commercialization. Cross-sectional research design was used. Two stage random sampling procedures were used for the selection of 160 representative sample households. Using probability proportional to size number of sample size was determined from each 4 representative kebele after Yamane formula was used to determine the total sample size. Semi- structured interview schedule was used for gathering primary data. Descriptive statistics, household commercialization intensity and double hurdle model were used for data analysis. The probit model result reveals that age, education level, distance to the nearest market, land holding size, access to market information and non/off-farm income significantly influence householdsparticipation decision in groundnut commercialization while the truncation model result disclose that age, education level, household size, land holding size and frequency of extension contact significantly influence the sample households' groundnut commercialization intensity. The findings have an implication for all the concerned body and they should have to develop strategies to address the aforementioned factors in order to improve smallholder farmers' groundnut commercialization.

Copy Right, IJAR, 2020,. All rights reserved.
\end{abstract}

\section{Introduction:-}

The agriculture sector is dominated by smallholder farming in Ethiopia. Smallholder agriculture represents about 95\% of the total agricultural output. In addition to producing staple crops, smallholders produce large share of export potential crops [1].Groundnut is an important crop from the perspective of food and nutrition security of poor smallholder farmers in developing countries [2].It also generates considerable cash income for small scale producers and foreign exchange earnings through export for Ethiopia [3]. According to [4], in 2014/2015 production year, groundnut covered about 64,643 ha of land at national level. Its production is expanding and has a huge potential as a cash and food crop to improve the livelihoods of farmers and traders in Ethiopia [5]. Eastern lowland areas of Ethiopia particularly Babile, Fedis, and Gursum are the major producers of groundnut for household consumption and income generation [6]. 
Commercializing smallholder agriculture is seen as a means to bring the welfare benefits of market-based exchange economies and central to an inclusive development process [7].Commercialization of agriculture is the strategy that the Ethiopian government is following to bring a dynamic change by transforming the traditional agriculture of smallholder farmers [8].The Plan for Accelerated and Sustainable Development to End Poverty, Ethiopia's strategic framework for (2005/06-2009/10), GTPI (2011-2015) and GTPII (2016-2020) relies on a massive push to accelerate growth.

In many parts of the country, market participation of smallholder farmers are limited and agricultural markets are fragmented and not well integrated into wider market systems, which increases transaction costs and reduces farmers' incentive to produce for market [9]. With the ever increasing population and the limited farm land, improving rural income will require transformation of the subsistence, low-input and low-productivity farming systems to agricultural commercialization.Its ultimate purpose is poverty alleviation and economic development through income growth. However, it has not been possible to achieve the desired effect of commercialization in subsistence agriculture because farmers' market participation is not motivated by profit-maximizing behavior[10]. They are still involved in local and regional markets and often do not have sufficient surplus production.

Various researches were conducted on groundnut production flow and little attention given for groundnut commercialization [11].The studies focused only on production marketing margins. Differentiation is important on the categories of household commercialization level in addition to identifying the determinant factors. There is knowledge gap on the determinant factors influencing the groundnut commercialization in the study area. The aim of this study is to identify factors determining farmers' participation decision and intensity of participation in groundnut commercialization in the study area.

\section{Research Methodology:-}

\section{Description of the Study Area:}

Babile is one of thedistrict of Eastern Hararghe zone. It is located to $557 \mathrm{~km}$ from Addis Ababa and35 km from Harar town. The district is bordered with Somali region in South, Fedis in East, Harari in West and Gursum in North. The altitude of the district ranges from 989-1700m.a.s. Agro-ecologically, 95\% of the district is lowland while the remaining $5 \%$ is mid-altitude. The annual rainfall ranges from 410 to $800 \mathrm{ml}$. The mean annual temperature of the area ranges between $24-28^{\circ} \mathrm{C}$ as information gathered from district in 2019.Based on [12], the district has an estimated population of 99,379 of which 50,025 are male and 49,354 are female. Mixed farming is the major livelihood activity in the area.Sorghum, Groundnut, Maize and Sesame are major cropsproduced in the area.Groundnut is one of the major oil crops grown in the district for income generation and consumption.

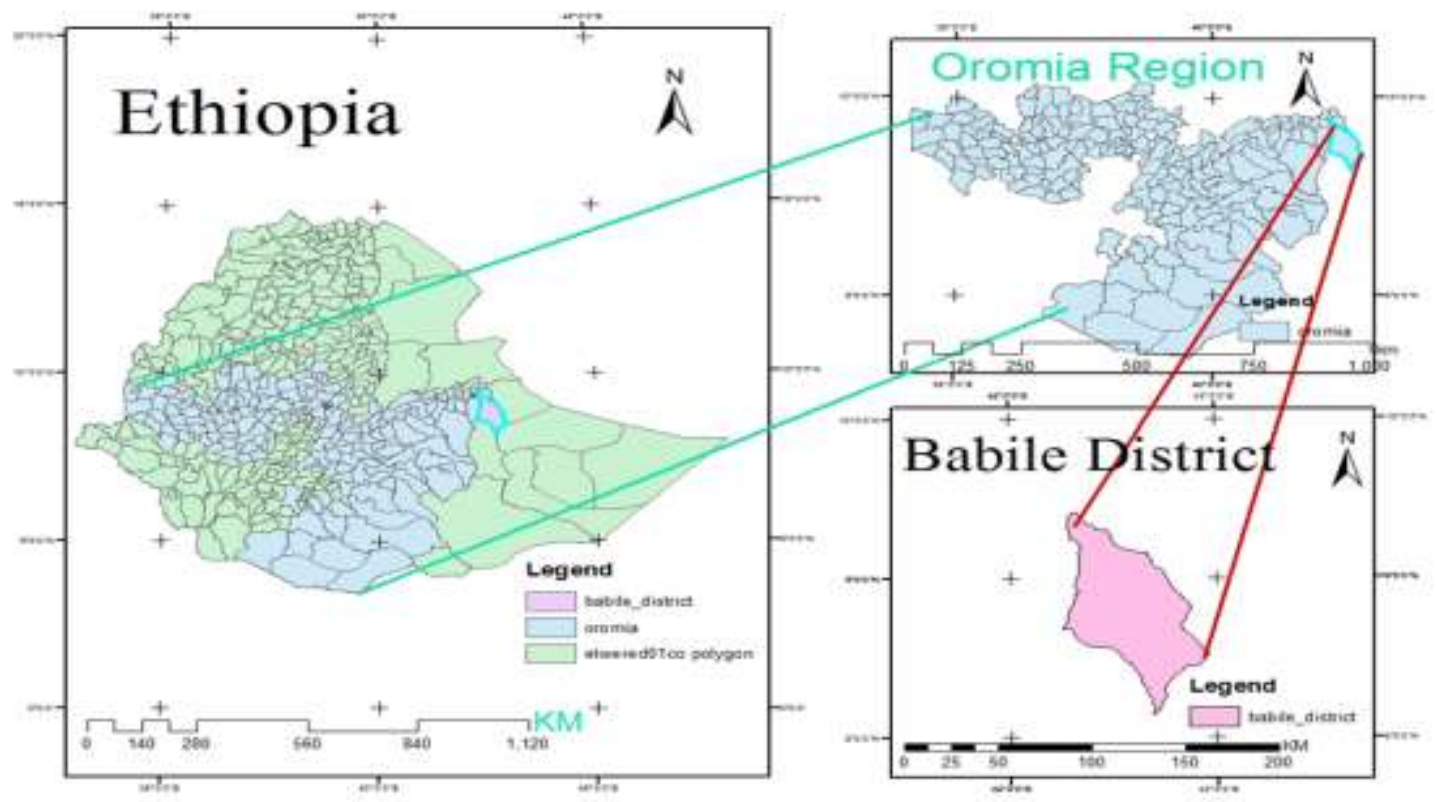

Figure 1:- Map of the study area. 


\section{Research Design:}

This research work was based on field work from randomly selected sample groundnut producers. Data were collected from sample respondents at one moment of time. Household surveywas used so as to achieve the objectives of the study.

\section{Sampling Procedures and Sample Size Determination:}

Babile district was selected purposively based on groundnut production potential. Two stage random sampling procedures were used for the selection of representative sample households. In the $1^{\text {st }}$ stage, 4 groundnut producer kebeles were selected from all groundnut producer kebeles through random sampling. In the $2^{\text {nd }}$ stage, 160 sample households were selected randomly from sampling frame of 2,422 groundnut producing households. This was determined by using Yamane formula [13].

$\mathrm{n}=\frac{\mathrm{N}}{1+\mathrm{N}\left(\mathrm{e}^{2}\right)}$

Where: $\mathrm{n}=$ sample size of groundnut producer households, $\mathrm{N}=$ groundnut producer household heads and $\mathrm{e}=$ level of precision (at 7.6\%). Sampling error (0.076) is considering the budget limitation and time utilization for the research study. Using probability proportional to size (PPS), number of sample size was determined from each representative kebele to avoid under representation of any one group.

$\mathrm{n}_{\mathrm{i}}=\frac{\mathrm{nN}_{\mathrm{i}}}{\Sigma \mathrm{N}}$

Where, $n_{i}=$ number of sample size from each kebele, $n=$ sample size determined (160), $N_{i}=$ number of groundnut producer household head of each kebele, $\mathrm{N}=$ target population.

Table 1:- Randomly selected kebeles and number of sample size determined by PPS.

\begin{tabular}{|l|c|c|c|}
\hline No & selected kebeles & Groundnut producer & sample determined by PPS \\
\hline 1 & Remeta Selama & 707 & 47 \\
\hline 2 & Barkale & 604 & 40 \\
\hline 3 & Ifadin & 506 & 33 \\
\hline 4 & Tula & 605 & 40 \\
\hline Total & & 2,422 & 160 \\
\hline
\end{tabular}

Source: own computation based on secondary data source, 2019

Data Types, Sources and Collection Methods:

Quantitative data were gathered from primary and secondary sources. Quantitative primary data was mainly focused on socio-economic and demographic characteristics, institutional factors and infrastructural facility related issues. The primary data sourcewas sample farm household heads. Primary data were collected from randomly selected groundnut producers'using a cross-sectional survey method throughsemi-structured interview schedule. Secondary data sources were collected from Babile district bureau of agriculture and natural resource,Central Statistical Agency (CSA) and journals by reviewing.

\section{Methods of Data Analysis:}

Descriptive statistics, Household Commercialization Intensity (HCI) and Double hurdle model were used for data analysis. Descriptive statistics was used to summarize and categorize the information gathered. Chi-square $\left(\chi^{2}\right)$ test was used for categorical variables to compare group proportions. The t-test was employed to compare group mean difference for continuous variables.In addition, HCI was used to determine households' level of groundnut commercialization. [14], explained as the ratio of percentage marketed output to total quantity produced. Mathematically expressed as follows:

$\mathrm{HCI}_{\mathrm{i}} \mathrm{g}=\left[\frac{\text { quantity of groundnut sold ij }}{\text { Total quantity of groundnut produced ij }}\right] * 100$

Where, $\mathrm{HCI}_{\mathrm{i}} \mathrm{g}$ is the ${ }_{\mathrm{i}}$ th farm $\mathrm{HCI}$ for groundnut; the numerator is the total quantity of groundnut sold by $\mathrm{i}_{\mathrm{i}}$ th farm household in year $\mathrm{j}$ (2018/19); the denominator is the total quantity of groundnut produced by the ith farmhousehold in the jth year. For this study, the intensity of commercialization is categorized into three based on [15].

\section{Econometric model specification:}

Double hurdle model is used assuming that the two decisions are exclusively independent. The decisions are modeled in the following manner:

The probit model is used to determine households' commercialization decision and its specification is given as: $\mathrm{y} *=\mathrm{x}_{\mathrm{i}} \beta+\varepsilon_{\mathrm{i}} \mathrm{N}(0,1)(4)$ 
$y_{i}=1$ if $y *>0$ and 0 otherwise where, $y *$ is a latent variable representing households' binary decision; $x_{i}$ is a vector of independent variables hypothesized to affect households' decision in the commercialization; $\beta$ is vector of parameters to be estimated by the model $; \varepsilon_{i}$ is a normally distributed error term andy $y_{i}$ is a discrete response variable. Truncated regression model was employed to explore the determinants of the households' intensity of commercialization. The intensity of commercialization is modeled as:

$\mathrm{z} *=\mathrm{x}_{\mathrm{i}} \gamma+\mu_{\mathrm{i}} \mathrm{N}\left(0, \delta^{2}\right)(5)$

$\mathrm{z}_{\mathrm{i}}=1$ if $\mathrm{z} *>0$ and 0 otherwise where, $\mathrm{z}_{\mathrm{i}}$ is the intensity of commercialization; $\gamma$ is vector of parameters to be estimated and $\mu_{\mathrm{i}}$ is the normally distributed error term.

\section{Results and Discussion:-}

\section{Descriptive Statistics Results:}

Demographic and socio-economic characteristics of sample households:

Of the total sample respondents, $87.5 \%$ were male-headed households while the remaining $12.5 \%$ were femaleheaded household (Table, 3). Of the total sample male-headed households, $74.4 \%$ participated in marketing their produce while $11.25 \%$ of female-headed household participated in marketing their groundnut produce. The mean age of sample household head was 37 years (Table, 2). The mean age of household head for participant in commercialization and non-participant was 36.09 and 42.35 years respectively. The mean education level of household head in formal schooling was 2.28years (Table, 2). The mean education level of household head for participants in commercialization and non-participant was 2.44 and 1.35 year in formal schooling respectively. The mean household size in adult equivalent was 5.11(Table, 2). The mean household size for participant in commercialization and non-participant was 4.99 and 5.78 in adult equivalent respectively.

The mean livestock owned in tropical livestock unit (TLU) was 3.23 (Table, 2). The mean livestock owned in tropical livestock unit for participants in commercialization and non-participants was 3.34 and 2.62 respectively. The mean land size of household heads in hectare was 1.16 (Table, 2). The mean land holding size of household heads for participants in commercialization and non-participants was 1.19 and 0.87 in ha respectively. The mean income generated from non/off-farm activities in thousand birr by sample household head was 3.44 (Table, 2). The mean income generated from non/off-farm activities by household heads for participants in commercialization and non-participants was 3.04 and 5.78 in thousand birrrespectively.

Table 2:- Descriptive statistics results for continuous explanatory variables.

\begin{tabular}{|l|l|l|l|l|l|l|l|}
\hline Variables & \multicolumn{2}{l}{$\begin{array}{l}\text { Participants } \\
\mathrm{n}=137\end{array}$} & \multicolumn{2}{l|}{$\begin{array}{l}\text { Non- participant } \\
\mathrm{n}=23\end{array}$} & \multicolumn{2}{l|}{$\begin{array}{l}\text { Total } \\
\mathrm{n}=160\end{array}$} & t-value \\
\hline & Mean & Std.dev. & Mean & Std.dev. & Mean & Std.dev. & \\
\hline Age of HH & 36.09 & 10.07 & 42.35 & 8.99 & 37 & 10.14 & $-3.04^{* * *}$ \\
\hline Education HH & 2.44 & 2.93 & 1.35 & 1.53 & 2.28 & 2.79 & $1.743^{*}$ \\
\hline Household SZ & 4.99 & 1.84 & 5.78 & 1.73 & 5.11 & 1.84 & $-2.014^{*}$ \\
\hline Dntm & 1.54 & 1.04 & 1.99 & 1.14 & 1.6 & 1.06 & $-1.776^{*}$ \\
\hline LVST & 3.34 & 3.39 & 2.62 & 3.6 & 3.23 & 3.42 & 0.886 \\
\hline Land SZ & 1.19 & 0.61 & 0.87 & 0.2 & 1.16 & 1.14 & $2.49^{* *}$ \\
\hline Extn.con. & 3.99 & 4.66 & 2.57 & 3.27 & 3.78 & 4.51 & $1.8^{*}$ \\
\hline NOFI & 3.04 & 6.59 & 5.78 & 5.78 & 3.44 & 6.53 & $-2.06^{* *}$ \\
\hline Credit & 0.88 & 2.76 & 0.15 & 0.42 & 0.77 & 2.57 & 1.27 \\
\hline SOur & & & & & &
\end{tabular}

Source: own survey result, 2019

Note $* * *(\mathrm{p}<0.01), * *(\mathrm{p}<0.05)$ and $*(\mathrm{p}<0.1)$ significant at $1 \%, 5 \%$ and $10 \%$, respectively.

\section{Institutional factors:}

About $62.5 \%$ of the sample household had access to market information while $37.5 \%$ of the sample respondents had no access to market information in the study area (Table, 3). The major sources of market information for the household head in the study area are neighboring farmers, development agents and traders. However, there is variation in access to market information from the aforementioned sources between participant in commercialization and non-participant. The mean frequency of extension contact in a year was 3.78 days (Table, 2). The mean frequency of extension contact provided for household heads for participant in commercialization and nonparticipant was 3.99 and 2.57 in days respectively. The mean credit received by the sample households' was 0.77 in thousand birr (Table, 2). 
The mean credit received by participant household in commercialization and non-participant was 0.88 and 0.15 in thousand birr respectively.

\section{Infrastructural (road) facility:}

The mean distance to the nearest market in walking hour was 1.6(Table, 2) while the mean distance for participantsand non-participantin commercialization was 1.54 and 1.99 in walking hour respectively.

Table 3:- Descriptive statistics results for dummy explanatory variables.

\begin{tabular}{|c|c|c|c|c|c|c|c|}
\hline \multirow[t]{2}{*}{ Variables } & \multicolumn{2}{|c|}{ Participant in commercialization } & \multicolumn{2}{|c|}{$\begin{array}{l}\text { Non-participant in } \\
\text { commercialization }\end{array}$} & \multicolumn{2}{|c|}{ Total } & \multirow[t]{4}{*}{$\chi_{\text {value }}^{2}$} \\
\hline & $\mathrm{N}$ & $\%$ & $\mathrm{~N}$ & $\%$ & $\mathrm{~N}$ & $\%$ & \\
\hline \multicolumn{7}{|l|}{ Sex of $\mathrm{HH}$} & \\
\hline Male & 119 & 74.4 & 21 & 13.1 & 140 & 87.5 & \\
\hline female & 18 & 11.25 & 2 & 1.25 & 20 & 12.5 & \multirow[t]{3}{*}{0.355} \\
\hline \multicolumn{7}{|c|}{ Acc.mrktinfn } & \\
\hline Yes & 94 & 58.75 & 6 & 3.75 & 100 & 62.5 & \\
\hline No & 43 & 26.88 & 17 & 10.625 & 60 & 37.5 & $15.2 * * *$ \\
\hline
\end{tabular}

Source: own survey result, 2019

Note: $* * *$, represents significant at $1 \%$

Household Commercialization Intensity (HCI):

According to [15] HCI is grouped into three categories based on the proportion of quantity supplied to the market. Low ( $<30 \%$ of output sold), medium (30\% $-75 \%$ of output sold) and high ( $>75 \%$ of output sold). Of the total sample household $85.6 \%$ were participated in groundnut marketing while the remaining $14.4 \%$ did not participate. Of the total sample households $52.5 \%$ and $33.1 \%$ fall in to medium and high categories respectively.

Table 4:- Commercialization categories based on proportion of quantity supplied to market.

\begin{tabular}{|l|l|l|}
\hline Level of commercialization & Frequency & Percentage (\%) \\
\hline Non-commercial household $(0 \%)$ & 23 & 14.4 \\
\hline Low $(<30 \%$ of output sold) & 0 & 0 \\
\hline Mediumcommercialized farmers (30-75\% of output sold) & 84 & 52.5 \\
\hline High commercialized farmers(>75\%of output sold) & 53 & 33.1 \\
\hline Total & 160 & 100 \\
\hline Minimum (\%) & 0 \\
\hline Maximum (\%) & 95 \\
\hline Average commercialization intensity $(\%)$ & 61.69 \\
\hline
\end{tabular}

Source: own computation/calculation, 2019

\section{Results of the econometric model:}

Variance inflation factor (VIF) for continuous explanatory variables while Tetrachoric correlations for dummy variableswere usedto detect high multicollinearity problem. The mean VIF was 1.2 which indicates no serious problem of multicollinearity among the variables in the model. Tetrachoric correlations less than 0.75 is appropriate. In this study it is less than 0.75. Breusch-Pagan/Cook-Weisberg test was employed to detect the heteroscedasticity problem. There was a problem of heteroscedasticity for the truncated part. Robust standard error was used to correct the problem of heteroscedasticity. Box plot graph was used to test for the extreme values of continuous explanatory variables. There was no serious problems of extreme values in the data and no dropped out data as extreme values.

\section{Determinantsof farmers' participation decision in groundnut commercialization:}

The probit regression model results shows that the function of participation decision in groundnut commercialization was highly significant at $1 \%$ level (Prob $>$ chi $\left.^{2}=0.0000\right)$ suggesting the model has strong explanatory power of independent variables to explain factors determining commercialization decision of households. Out of the 11 explanatory variables used in the probit model, six variables: age of household heads, education level of household heads, distance to the nearest market, land size, access to market information and income generated from non/offfarm activities were found to significantly influences the farmers participation decision in groundnut commercialization in the study area (Table, 5). 


\section{Age of household heads (Age of $\mathbf{H H}$ ):}

The result shows that age has negativeeffecton the farmers' participation decision in groundnut commercialization at $1 \%$ significance level (Table, 5). The marginal effect after probit indicated that as age of household head increases by 1 year, it decreases the farmers' participation decision in groundnut commercialization by $0.11 \%$ keeping all other factors constant.This shows that involving active labor force in agricultural activities increases the probability of participation decision in groundnut commercialization. Furthermore, older household takes the low profit with low risk rather than taking high profit with high risk. This result is consistent with the finding of [16] that age has negative effect in market participation decision.

\section{Education level of household head (Education HH):}

It had negative and significant influences on the farmers' participation decision in commercialization of groundnut at 5\% significance level (Table, 5). This indicates that attending formal education may create other job opportunities to participate in non-agricultural activities as employee. Marginal effect indicated that for each additional year in formal education, the farmers' participation decision in groundnut commercialization decreases by $0.18 \%$ holding all other factors constant.This result is contrast with the findingof [17] that education level influence farmers' participation decision positively.

\section{Distance to the nearest market (Dntm):}

Was negatively and significantly influences the farmers' participation decision in commercialization of groundnut at $1 \%$ significance level (Table, 5). Marginal effect of this variable revealed that a unit incremental in walking hour decreases the probability of farmers' participation decision in commercialization by $0.97 \%$ keeping all other factors constant. This implies thatlong time taken to cover distance to the nearest market required high transaction costs or high cost of doing business like transportation costs and personal expenses that decrease farmers' participation decision in groundnut commercialization. This finding is consistent with the finding of [18].

\section{Land holding size (Land SZ):}

It was found to have positive and significant influences on the farmers' participation decision in commercialization of groundnut at $1 \%$ significance level (Table, 5). Marginal effect indicated that as the land size increases by 1 hectare the probability of farmers' participation decision in commercialization increases by $3.91 \%$ holding all other factors constant. This implies that land is one of the factors of production which helps farmers to allocate their land for different crops. This result is in line with the finding of [19] that as the land size increases, the probability of decision for commercialization increases.

\section{Access to market information (Acc.mrktinfn):}

Found to have positive and significant influences on the farmers' participation decision in groundnut commercialization at $1 \%$ significance level (Table, 5). Marginal effect of this variable after probit regression disclosed that as farmer's has access to market information the probability of participation decision in commercialization increases by $2.16 \%$ keeping all other factors constant. This indicates that access to market information helps farmers' to be market oriented for their production (when and where to sell). This study is in line with the finding of [20] that access to market information has a positive and significant impact on the households' market participation decision.

\section{Non/off-farm income (NOFI):}

It hadnegative and significant influences on the farmers' participation decision ingroundnut commercialization at $10 \%$ significance level (Table, 5). Marginal effect of the variable indicated that as the income generated from non/off-farm activities increases by thousand birr the probability of participationdecision in commercialization decreases by $0.07 \%$ keeping all other factors constant.The possible reason is that groundnut commercialization is risk bearing agricultural activities as compared to non/off-farm income generating activities. Furthermore, engagement in non/off-farm activities easily generates income in a short period of time. This finding is in line with the finding of [21] that getting more non/off-farm income represents additional wealth which constrain household not to participate in cash crops.

Table 5:- Determinants of farmers' participation decision in groundnut commercialization.

\begin{tabular}{|l|l|l|l|l|}
\hline Variables & Coefficient & Robust Std. Err & $\mathrm{P}>|\mathrm{z}|$ & Marginal effect \\
\hline Constant & $4.1504 * * *$ & 1.0943 & 0.000 & \\
\hline Sex of HH & .0004 & .5122 & 0.999 & $5.08 \mathrm{e}-06$ \\
\hline
\end{tabular}




\begin{tabular}{|l|l|l|l|l|}
\hline Age of HH & $-.0795^{* * *}$ & .0210 & 0.000 & -.0011 \\
\hline Education HH & $-.1299^{* *}$ & .0533 & 0.015 & -.0018 \\
\hline Household SZ & -.1153 & .0950 & 0.225 & -.0016 \\
\hline LVST & -.0071 & .0585 & 0.903 & -.0001 \\
\hline Land SZ & $2.7621^{* * *}$ & .6245 & 0.000 & .0391 \\
\hline NOFI & $-.0473^{*}$ & .0265 & 0.075 & -.0007 \\
\hline Acc.mrktinfn & $.9485 * * *$ & .3385 & 0.005 & .0216 \\
\hline extn.con. & .0205 & .0383 & 0.593 & .0003 \\
\hline Credit & .0955 & .1602 & 0.551 & .0014 \\
\hline Dntm & $-.6853^{* * *}$ & .2142 & 0.001 & -.0097 \\
\hline
\end{tabular}

Number of obs $=160 \quad$ Log likelihood $=-32.229575$

Wald chi2 $(11)=48.26 \quad$ Prob $>$ chi2 $=0.0000$

Pseudo R2=0.5107

Source: own survey result, 2019

Note: $* * *, * * * *$ represents significant at $1 \%, 5 \%$ and $10 \%$ level respectively.

Determinants of farmers in groundnut commercialization intensity:

The factors determining intensity of commercialization were analyzed by using truncated regression model. Detailed discussions are given on the significant variables hereunder.

Age of household heads (Age of $\mathrm{HH}$ ):

It was found to be negatively influences the groundnut commercialization intensity at $1 \%$ significance level (Table, 6). As the coefficient of age of the farmer's increases by 1 year, the proportion of quantity sold to the market decreases by $0.49 \%$ holding all other variables constant. This implies that active labor force in agricultural product is more actively engaged in groundnut supply to the market as compared to their older counterpart. The finding of this study is in line with the finding of [22] that, younger households are generally sell more product than their older counterparts.

\section{Education level of household heads (Education HH):}

Found to have positive and significant influences onintensity of groundnut commercialization at 5\% significance level (Table, 6). The coefficient of education level indicates that as farmers' formal education level increases by one grade the farmers' groundnut commercialization intensity increases by $0.5 \%$ keeping all other factors constant. This shows thateducationimproves skills and knowledge of the farmers which enhance production and supply more proportion. The finding of this study is in line with [23] which indicated that educated farmers have ability of analyzing market condition and better exposure to the new ideas emerging from market.

\section{Household size (Household SZ):}

Was found to negatively influences the groundnut commercialization intensity at 5\% significance level (Table, 6). The coefficient of household size indicates that as household size increases by one in adult equivalent the proportion of groundnut quantity supplied to the market decreases by $1.15 \%$ keeping all other factors constant. This disclose that as family members increase the number of dependence ratio increases and the proportion of quantity for consumption purpose increasesthat makes quantity supplied to the marketdecreases. The finding of this study is consistent with [24] that the higher the family size the lower will be the quantity marketed.

\section{Land holding size (Land SZ):}

Was found to positively influence the groundnut commercialization intensity at $1 \%$ significance level (Table, 6). The coefficient of the land size indicates that as farmer's land size increases by one more hectare the farmers' proportion of quantity supplied to the market increases by $9.13 \%$ all other factors held constant. This reveals that as cultivated land size increases the probability of land allocation for high value crops increases which internboost the production of farmers' and the proportion of quantity supplied to the market. This finding is similar with the finding of [25] that land size positively influences the intensity of market participation.

\section{Frequency of extension contact (extn.con.):}

It was found to statistically significant and positively influences farmers' groundnut commercialization intensity at $1 \%$ significance level (Table, 6).The coefficient of this variable indicates that as farmers' get one day extension 
contact the farmers' proportion of groundnut supplied to the market increases by $0.54 \%$ keeping all other factors constant.This indicates that extension contact on awareness creation about new technology, agronomic practice, theoretical and practical training on groundnut commercialization can be used as an input for capacity building to upgrade existing indigenous knowledge of farmers that have an implication on increasing proportion of quantity supplied to the market.This study is similar with the findingof [26], indicated that extension contact increases the quantitysupplied to market.

Table 6:- Truncated result for farmers' groundnut commercialization intensity.

\begin{tabular}{|l|l|l|l|}
\hline Variables & Coefficient & Robust Std. Err. & $\mathrm{P}>|\mathrm{Z}|$ \\
\hline Constant & $.7848^{* * *}$ & .0472 & 0.000 \\
\hline Sex HH & .0081 & .0210 & 0.700 \\
\hline Age of HH & $-.0049^{* * *}$ & .0008 & 0.000 \\
\hline Education HH & $.0050^{* *}$ & .0024 & 0.033 \\
\hline Household SZ & $-.0115^{* *}$ & .0057 & 0.043 \\
\hline LVST & .0018 & .0017 & 0.307 \\
\hline Land SZ & $.0913^{* * *}$ & .0146 & 0.000 \\
\hline NOFI & .0009 & .0012 & 0.456 \\
\hline Acc.mrktinfn & .0026 & .0216 & 0.906 \\
\hline extn.con. & $.0054^{* * *}$ & .0018 & 0.003 \\
\hline Credit & .0034 & .0032 & 0.286 \\
\hline Dntm & .0055 & .0076 & 0.470 \\
\hline
\end{tabular}

Number of obs $=137 \quad$ Wald chi2(11) $=167.21$

Log likelihood $=137.05366$ Prob $>$ chi2 $=0.0000$

Source: own computation from survey result, 2019

Note: $* * *$ and $* *$ represents significance level at $1 \%$ and $5 \%$ respectively.

\section{Conclusion:-}

Farm households' groundnut commercialization decision has association with different factors. The factors such as age of household heads, education level of household, landholding size, access to market information, non/off -farm income and distance to the nearest market have significant relationships with farm households' groundnut commercialization decision. This suggests that households' commercialization decision being influenced by different factors. Similarly households' intensity of groundnut commercialization has relationship with different factors. Factors such as age of household head, education level of household head, household size, landholding size, frequency of extension contact significantly influence the farm households' commercialization intensity. This implies that farmers' groundnut commercialization intensity being influenced by different factors. Generally smallholder farmers' groundnut commercialization decision and intensity of commercialization being influenced by different factors in the study area.

\section{Recommendations:-}

The following recommendations are given based on theresults of probit and truncated regression model.

Age of sample respondent has negative relationship with bothparticipation decisionin groundnut commercialization and its intensity. Therefore, both government and non-government organization should introduce capital intensive technologies in order to increase participation of older farmers in groundnut production and commercialization. Likewise, distance to the nearest market negatively and significantly influences households' participation decision in groundnut commercialization.Government should strengthen and promote better access to quality road and transportation facilities to help farmers to participate in commercialization decision with low transaction costs. The result indicates that education level positively and significantly influences the intensity of farmers' in groundnut commercialization. Hence, government should capitalize on capacity building in order to enhance farmers' awareness and knowledge through adult education program.

Land size positively and significantly influences both farmers' commercialization decision and intensity of commercialization. Since expansion of cultivation land is impossible in the study area. Agriculture and natural resource sector should encourage farmers to use intensive farming system by using full packages of technologies on 
scarce land resource to increase production and quantity of groundnut supplied tomarket.Access to market information has also positive influences on households' commercialization decision. Therefore, extension organization and farmers' cooperatives should deliver reliable market information on time to help farmers benefit from groundnut commercialization. Household size negatively and significantly influences intensity of commercialization. Hence, it is better if health sector strengthen awareness on family planning in order to decreasedependence ratio to enhance proportion of quantity supplied to market. Frequency of extension contact positively and significantly influences household commercialization intensity. Therefore, it is better if agricultural researchers, experts and development agents' work together to build farmers' capacity in order to increase frequency of extension contact to enhance groundnut commercialization intensity.

\section{References:-}

1. FAOSTAT.2014.Retrievedfromhttp://www.faostat.fao.org.http://dx.doi.org/10.1016/j.foodpol.2005.12.003

2. Nedumaran, S., Abinaya, P., Jyosthnaa, P., Shraavya, B., Parthasarathy, R. and Cynthia, B. 2015. Grain Legumes Production, Consumption and Trade Trends in Developing Countries. ICRISAT, No. 60.

3. Geleta Tarekegn., Purshotum, K.S., Wijnand, J.S, and Tana Tamado. 2007. Integrated management of GroundnutRoot Rot Using Seed Quality and Treatment. International Journal of Pest Management, 53(1): 5357.

4. Central Statistical Agency (CSA). 2015. Statistical report on area and crop production, Addis Ababa, Ethiopia.

5. Daniel, E. 2009. Groundnut research. In Presentation for Workshop (pp. 1-3) Ethiopia: Werer Agricultural Research Center.

6. Chala, A., Mohammed, A., Ayalew, A., and Skinnes, H. 2013. Natural occurrence of aflatoxins in groundnut (Arachis hypogaea L.) from Eastern Ethiopia. Food Control, 30:602-605. http://dx.doi.org/10.1016/j.foodcont.2012.08.023

7. Arias, P., Hallam, D., Krivonos, E. and Morrison, J. 2013. Smallholder integration in changing food markets. Food and Agriculture Organization of the United Nations, Rome.

8. Afework Hagos and Endrias Geta. 2016. Review on smallholders' agriculture commercialization in Ethiopia: What are the driving factors to focused on? Journal of Development and Agricultural Economics, 8(4): 65-76.

9. Mitku, A .2014. Impact of smallholder farmers' agricultural commercialization on rural households' poverty. Int. J. Appl. Econ. Finance, 8:51-61.

10. Barrett, C.B.2008. Smallholder market participation: concepts and evidence from Eastern and Southern Africa. Food Policy, 33 (4):299-317.

11. Addisu Getahun and Erimias Tefera.2017. Value Chain Assessment Study of Groundnut in Northwestern Ethiopia. British Journal of Economics, Management and Trade 16(2): 1-15.

12. Central Statistical Agency (CSA) .2008. Population survey, Addis Ababa, Ethiopia.

13. Yamane, T. 1967. Statistics: An Introductory Analysis, 2nd Edition. Harper and Row, Publisher, New York.

14. Mather, D., Boughton, D. and Jayne, T. S. 2013. Explaining smallholder maize marketing in Southern and Eastern Africa: The roles of market access, technology and household resource endowments. Food Policy, 43: 248-266.

15. Osmani, M. A. G., Khairul, I., Bikash, C.G. and Hossain, M.E. 2014. Commercialization of smallholder farmers and its welfare outcomes. Evidence from Durgapur Upazila of Rajshahi District, Bangladesh.

16. Edosa Tadesa Leta.2018.Determinants of commercialization of teff crop in Abay Chomen District, Horo Guduru wallaga zone, Oromia Regional State, Ethiopia. Journal of Agricultural Extension and Rural Development, 10 (12): 251-259.

17. Christopher Sebatta, Johnny Mugisha, Enid Katungi, Apolo Kashaaru and Harriet Kyomugisha.2014.Smallholder Farmers' Decision and Level of Participation in the Potato Market in Uganda, 5: 895-906.

18. Tufa Aman, Bekele Adam and Zemedu Lemma.2014.Determinants of smallholder commercialization of horticultural crops in Gemechis District, West Hararghe Zone, Ethiopia. African Journal of Agricultural Research, 9(3): 310-319.

19. Ataul Gani Osmani and Elias Hossain.2015. Market Participation Decision of Smallholder Farmers and Its Determinants in Bangladesh. Journal of Economics of Agriculture, 62 (1):163-179.

20. Yassin Esmael Ahmed, Adam Bekele Girma and Mengistu Ketema Aredo .2016. Determinants of Smallholder Farmers Participation Decision in Potato Market in Kofele District, Oromia Region, Ethiopia. International Journal of Agricultural Economics, 1(2): 40-44.

21. Gabriel Temesgen.2017. Small Scale Irrigation and Agricultural Commercialization in Tigray. G.J.C.M.P., (2):87-94. 
22. Abafita, J., Atkinson, J. and Kim, C.S.2016.Smallholder Commercialization in Ethiopia: Market Orientation and Participation. International Food Research Journal, 23(4):1797-1807.

23. Ibrahim Aliyi, Beyene Tadesse and Tinsae Demise.2018. Determinants of intensity of market participation of smallholder rice producers: The case of Shebe Sombo District, Southwest Ethiopia. Journal of Agricultural Economics and Development, 7(3):13-22

24. Yallew Mazengia.2016.Smallholders' commercialization of maize production in Guangua district, Northwestern Ethiopia, WSN 58: 65-83.

25. Nwalem Monday Patrick, Ukpe Udeme Henrietta, Djomo Raoul Fani, Dzever Donald.2016. Factors Influencing Market Participation among Sesame Producers in Benue State, Nigeria, IJRSAS, 2(5): 1-5.

26. Tadele Melaku, Mulu Debela and Mansingh, P. 2016. Factors Affecting Teff and Wheat Market Supply in Dendi District, West Shoa Zone, Ethiopia. International Journal of Current Advanced Research, 5(4): 811-816. 